\title{
Assessment and mapping of flood potential in the Slănic catchment in Romania
}

\author{
Liliana Zaharia ${ }^{1}$, Romulus Costache ${ }^{1,2, *}$, Remus PrăvăLie ${ }^{1}$ and Gabriel Minea ${ }^{2}$ \\ ${ }^{1}$ Faculty of Geography, University of Bucharest, 1, Nicolae Bălcescu Boulevard, 010041 Bucharest, Romania. \\ ${ }^{2}$ National Institute of Hydrology and Water Management, Şos. Bucureşti-Ploieşti 97, \\ Sector 1, Bucureşti, România. \\ ${ }^{*}$ Corresponding author. e-mail: romuluscostache2000@yahoo.com
}

Flood risk assessment is an important component of risk management. Given this context, this paper aims to identify and map areas with high potential for flash-floods and flooding occurrence, at different spatial scales (from catchment to local scale), in order to estimate the flood/flooding vulnerability. The paper is based on three main methods, which were applied in the Slănic River catchment $\left(427 \mathrm{~km}^{2}\right)$, located in the external curvature region of the Romanian Carpathians: (i) statistical analyses; (ii) determination and mapping of some indices to assess the flash-flood and flooding potential (FFPI and respectively FPI) and (iii) hydraulic modelling. The data used mainly include hydrological statistics (maximum monthly and annual discharges, flood-related data) and spatial data on catchment geographical characteristics (hypsometry, geology, soils, land use) obtained or derived from various sources (maps, aerial images, digital databases, field measurements) which were integrated into the GIS environment. The aforementioned methods helped to (i) highlight specificities of floods in the Slănic catchment (magnitude, frequency, flood waves characteristics); (ii) identify areas with high potential for flash-floods and flooding at the catchment spatial scale; (iii) assess the structural vulnerability in the Cernăteşti village, by simulating flood-prone areas for flood peaks with exceedance probability of $1 \%, 5 \%$ and $10 \%$. The results could lead to a better knowledge and understanding of flood characteristics in the study area, in order to mitigate the flood risk through a more effective management, both at the catchment scale, as well as local scale (in the Cernăteşti village).

\section{Introduction}

Hydrological disasters (floods and wet mass movements) have globally the largest share in natural disaster occurrence: $49 \%$ between 2000 and 2008, of which floods alone represent $44 \%$. In 2012, hydrological events caused $52 \%$ of total disaster victims, and were responsible for $42 \%$ of the total reported number of people killed and $16 \%$ of total damages (Below et al. 2009; Guha-Sapir et al. 2013). On a global scale, floods caused by heavy rain have a high frequency (Townsend and Walsh 1998;
Dutta et al. 2000; Dolcine et al. 2001; Sheng et al. 2001; Bryant and Rainey 2002; Hudson and Colditz 2003; Knebl et al. 2005). Among European countries, Romania deals with one of the highest flood risks (Roo et al. 2007; Kundzewicz et al. 2014). Almost half $(48 \%)$ of the total of 90 natural disasters recorded between 1900 and 2013 in Romania were floods. They were responsible for $35 \%$ of the total number of disaster-linked deaths and also for $80 \%$ of the event-affected population, generating $50 \%$ of the total damage cost caused by these calamities (EM-DAT 2013).

Keywords. Flash-flood; flooding; hydraulic modelling; structural vulnerability; Slănic catchment; Romania. 
Over the past decades, flood risk assessment, both hazard and vulnerability analysis, that together could potentially harm exposed people, property, services, livelihoods and the environment (UNISDR 2009) has become increasingly relevant. In Europe, the assessment and management of flood risks is regulated by the 2007/60/EC DIRECTIVE (DEPC 2007), which states that "in order to have available an effective tool for information, as well as a valuable basis for priority setting and further technical, financial and political decisions regarding flood risk management, it is necessary to provide for the establishing of flood hazard maps and flood risk maps showing the potential adverse consequences associated with different flood scenarios." (DEPC 2007).

Given this context, the present paper aims to assess the flood and flooding potential in order to identify and map the areas with high potential for flash-floods and flooding, and finally to estimate the structural vulnerability of flooding. In specialized literature, there are several methods used to identify areas exposed to flash-flood and flooding. The following indices were used in our paper: FFPI (Flash-Flood Potential Index) (Smith 2003; Teodor and Mătreaţă 2011; Zaharia et al. 2012; Fontanine and Costache 2013; Minea 2013; Prăvălie and Costache 2013) and FPI (Flooding Potential Index) (Shaban et al. 2001, 2006; Kourgialas and Karatzas 2011; Costache and Prăvălie 2012). These indices are obtained by integrating in the GIS environment several geographical factors influencing on the one hand, the surface runoff (FFPI), in order to identify areas with high potential of hillslope runoff, susceptible to flash-flood occurrence, and on the other hand, the water accumulation and flooding (FPI), in order to identify flood-prone areas. The use of the abovementioned indices is mainly recommended for large areas (for instance, river catchment scale), for identifying areas with high susceptibility to flash-floods and flooding. For these large areas, the analysis can be detailed using hydraulic models which allow the flood-prone area delineation for flood peaks with various return periods, which can help to estimate the flood risk by identifying the potentially affected socio-economic elements. In specialized studies, hydraulic modelling is mostly performed by using the HEC-RAS open source software (Devon 2003; Brazdil et al. 2006; Wallace et al. 2006; Cesur 2007; Magirl et al. 2008; Papadimitrakisi and Orphanos 2009; Remo et al. 2009; Wyrick et al. 2009; Alexandrescu 2010; Daraio et al. 2010; Koutroulis and Tsanis 2010; Anderson and Neff 2011; Di Baldassare and Ciaps 2011; Armaş et al. 2012; Haliuc and Frantiuc 2012; Saleh et al. 2013; Costache et al. 2015).

This paper highlights three major issues:

- flood analysis of the Slănic River (magnitude, frequency and flood wave characteristics between 1970 and 2010);
- determining and mapping the FFPI and FPI indices to assess the flash-flood and flooding potential for the whole Slănic catchment, and

- delineation by hydraulic modelling of the floodprone areas, for flood peaks with different exceedance probabilities in Cernăteşti village, and structural vulnerability assessment, by identifying buildings and roads potentially affected by the simulated floods.

\section{Study area}

The study area covers the Slănic river catchment (length $73 \mathrm{~km}$, area $427 \mathrm{~km}^{2}$ ), which is located in the central south-eastern part of Romania, in the external curvature of the Carpathian Mountains, at altitudes ranging from 1400 to $120 \mathrm{~m}$ a.s.l. (figure 1). It is a 1st order subcatchment of the Buzău River catchment and a 2nd order subcatchment of the Siret River, with a north-south-oriented elongated shape and a maximum width of about $10 \mathrm{~km}$. The upper sector (up to the Lopătari village) covers a mountainous area consisting mainly of Paleogene and Miocene flysch. Most of the catchment overlaps the Sub-Carpathians, which consist of Miocene deposits (sometimes surface-breaching marls, clays, saltdiapir) and Pliocene molasse deposits (gravels, sands, clays). In the lower sector quaternary deposits are dominant (loess, silts). The mountainous and subCarpathian sectors are located in an upward vertical tectonic movement area (reaching $+2 \cdots+4$ $\mathrm{mm} /$ year in the mountainous area), while the lower sector is in an area affected by downward movements. As a result, the main process in the upper and middle sectors is erosion, while in the lower sector, the most active processes are accumulative (Grecu et al. 2007), favouring the river overflow.

Slănic River multiannual mean discharge is fairly low: $0.8 \mathrm{~m}^{3} / \mathrm{s}$ for its upper course (at Lopătari gauging station) and $1.08 \mathrm{~m}^{3} / \mathrm{s}$ at Cernăteşti gauging station, $4 \mathrm{~km}$ upstream from its confluence with Buzău (between 1950 and 2010, based on data provided by 'Romanian Waters' National Administration, Buzău-Ialomiţa Water Branch - BIWB 2013). In the mentioned period, the mean annual discharges ranged at Lopătari from 0.22 to 1.82 $\mathrm{m}^{3} / \mathrm{s}$, and at Cernăteşti, from 0.38 to $2.99 \mathrm{~m}^{3} / \mathrm{s}$, with similar coefficients of variation for the two gauging stations (0.5), which points to a relatively important variability of the mean annual discharge.

The mean annual rainfall amounts increase from about $530 \mathrm{~mm}$ in the lower sector to over $800 \mathrm{~mm}$ in the mountainous area; the highest rates were recorded from May to July, while the lowest in September, October and January (Grecu et al. 2007). Due to its geographical position, the Slănic catchment is affected by the foehn phenomenon, 


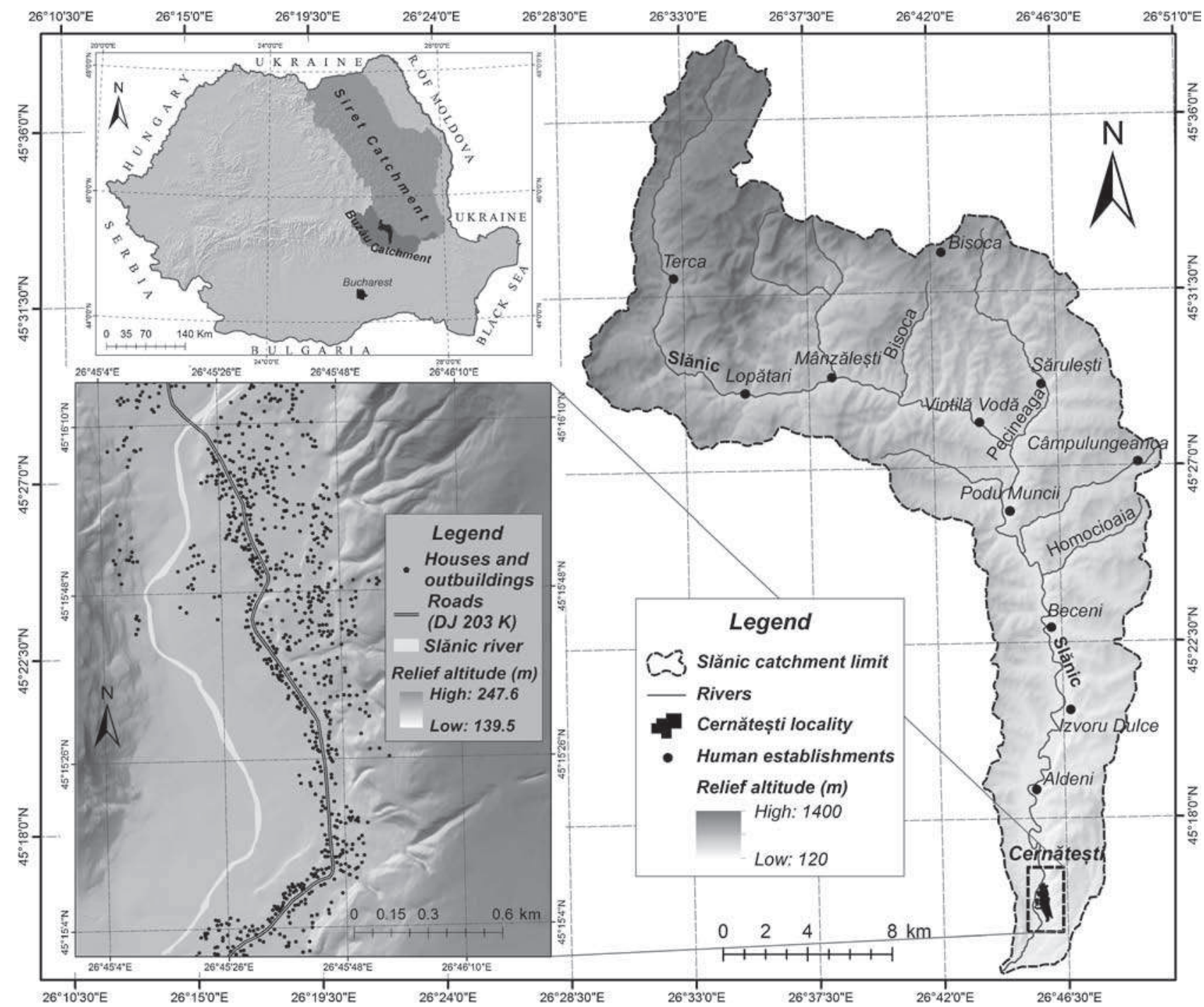

Figure 1. Location of the Slănic catchment and Cernăteşti settlement.

causing low rainfall (Ion-Bordei 1988), and consequently low streamflow. However, summer rains are usually torrential, which favour flood occurrence.

The annual flow regime is characterized by high discharges between March and June (11-15\% of the annual mean volume, reaching its peak in April, with $14.7 \%$ at Lopătari and $14 \%$ at Cernăteşti) and low flow (approx. 4\%) in September and October. Floods are linked to the warm season (May-September), as they are mainly caused by heavy rainfall. The highest flood recorded in the Slănic catchment, between 1961 and 2010, occurred in the summer of 1975 , as a result of very important rainfall recorded on 2 July - 132.5 mm at Lopătari (Mustățea 2005), which generated exceptional flood peaks on Slănic river: $215 \mathrm{~m}^{3} / \mathrm{s}$ at Lopătari and $410 \mathrm{~m}^{3} / \mathrm{s}$ at Cernăteşti.

The most recent event took place on 29 May 2012, when, due to heavy rainfall in the upper Slanic catchment (where the $78.2 \mathrm{~mm}$, recorded in less than a day at the Bisoca weather station, represented approx. $10 \%$ of the station's total annual mean rate) and the accelerated surface runoff, a flood with a peak of $92.4 \mathrm{~m}^{3} / \mathrm{s}$ was recorded at Cernăteşti, where some areas were flooded (Costache and Prăvălie 2013).

Some of the geographical features favouring flash floods and flooding in the Slănic catchment are: a low forestation (approx. $40 \%$ of the total area), slopes (about $30 \%$ of the catchment surface has slopes above $15^{\circ}$ ), and relatively high drainage density (over $3 \mathrm{~km} / \mathrm{km}^{2}$ in certain catchment areas), with a high frequency of torrents in the upper and middle sectors of the catchment.

In the geographical conditions specific to the Slănic catchment, the lag time (period of time between the peak rainfall and peak discharge) is about $7 \mathrm{hr}$ (426 min). It was determined based on the DHI (2009) equation (1):

$$
T_{\text {lag }}=\frac{\left(L * 3.28 * 10^{3}\right)^{0.8} *\left(\frac{1000}{C N_{\mathrm{aw}}}-9\right)^{0.7}}{1900 * Y^{0.5}},
$$


where $T_{\text {lag }}=$ lag time, in hours; $L=$ hydraulic length of the catchment, in $\mathrm{km} ; C N_{\text {aw }}=$ average curve number within the catchment area; $Y=$ average catchment slope, in percent.

A short lag time can be an indicator that the area around a river can be affected by flash-floods if short heavy rainfalls occur (Costache 2014). The information lag time is important for infrastructure engineers and environmental protection planners to take appropriate measures for protecting people and property from the effects of flooding.

The population density over the whole basin is about 50 inhabitants $/ \mathrm{km}^{2}$. The population is entirely rural, concentrated in eight communes to talling 62 villages, half of which are located along the Slănic River, and therefore exposed to floods. According to the Corine land cover database (CLC), the built area covers approx. $10 \%$ of the total catchment area (CLC 2006). The main economic activity is subsistence agriculture (growing plants and livestock raising on pastures and meadows). Agricultural land occupies $44 \%$ of the basin surface, of which arable land represents $60 \%$. Among the industrial activities, the most important ones are forest exploitation and gravel mining. Over the past few years, there has been a certain rise of tourism-related activities.

The population, the socio-economic activities and transport infrastructure are subjected to flash-floodrelated phenomena as flooding, hillslope and channel dynamic processes. The flood vulnerability in Slănic catchment is increased by the fact that it is low engineered: there are no reservoirs and other major technical measures for flood protection, but only some isolated local levees.

Cernăteşti settlement, located on the lower course of the Slănic river, $4 \mathrm{~km}$ upstream from its mouth,was chosen for detailed analysis in order to delineate flood-prone areas using the HEC-RAS hydraulic model. The modelled area is approx. $2 \mathrm{~km}$ long and covers approx. $4 \mathrm{~km}^{2}$. The choice of this settlement is justified by the fact that, according to the calculated FPI, it has a high flooding potential. Moreover, the town's flood vulnerability is rather high, because of the number of inhabitants (3920 in 2011, according to the Statistics Bureau in the Buzău county), the economic importance of the agricultural land (out of the commune's total surface of $50 \mathrm{~km}^{2}$, approx. $60 \%$ is covered by agricultural land, half of which is arable), and of the road infrastructure (the most important is the one connecting the villages located in the Slănic catchment). In 2011, 2012 and the first half of 2013, Slănic river floods caused significant damage to the area, mainly affecting the roads, bridges and footbridges (according to the Buzău County Emergency Inspectorate). An important reason for focusing the analysis in Cernăteşti is the presence of a local gauging station for providing hydrological data.

\section{Data and methodology}

The two main data types used were hydrological and spatial.

The hydrological data include monthly and annual mean discharges (from 1950 to 2010), monthly and annual maximum discharges (from 1970 to 2010) and flood data recorded on Slănic River at Cernăteşti gauging station, which covers $99 \%$ of the catchment area. The data were validated and provided by the National Institute of Hydrology and Water Management (NIHWM).

The spatial data address geographical features of the Slănic catchment (hypsometry, geology, soils and land use). They were obtained from various sources, in both classical and digital formats: cartographic documents (topographic, geological and pedological maps, local plans), aerial images (2008, Orthophotomaps), digital database (SRTM altimetry database, Corine land cover database) and field measurements. These data were processed in the GIS environment with the ArcGIS 10.1 software.

The methodology is mainly based on three methods:

(i) statistical,

(ii) determination and mapping of flood/flooding potential assessment specific indices, and

(iii) hydraulic modelling for simulating the floodprone areas.

The statistical methods include statistical parameter determination, trend identification and frequency analysis. The linear trend statistical significance was analysed using the Mann-Kendall test (Salmi et al. 2002). The frequency analysis aimed to determine the major flood frequency and to estimate the flood peaks with different exceedance probabilities (using the Pearson type III distribution), based on which the flood-prone areas were simulated by hydraulic modelling.

The flood/flooding potential assessment index method: As mentioned in the introduction, two indices were considered: the FFPI (flash-flood potential index) used to identify areas with accelerated surface runoff, favouring flash-flood occurrence, and the FPI (flooding potential index), used to identify flooding-prone areas. The indices were estimated and mapped at the catchment scale.

To calculate the FFPI, influencing the velocity of the surface runoff, the following 10 variables were considered: land slope, land cover, profile curvature, soil texture, L-S factor (length and slope gradient ratio), lithology, rainfall intensity, basin network convergence index, drainage density 
Table 1. Weighing and classification of geographical factors for determining the FFPI index in the Slănic catchment.

\begin{tabular}{|c|c|c|c|c|c|}
\hline Parameters/weight (\%) & & & Types/values & & \\
\hline Slope $\left({ }^{\circ}\right): 14.48 \%$ & $0-5$ & $5-10$ & $10-20$ & $20-30$ & $>30$ \\
\hline $\begin{array}{l}\text { Land cover/use: } \\
14.48 \%\end{array}$ & $\begin{array}{l}\text { Decidous forest, } \\
\text { coniferous forest, } \\
\text { mixed forest }\end{array}$ & $\begin{array}{l}\text { Orchards, transitional } \\
\text { woodland-shrub, } \\
\text { beaches, dunes }\end{array}$ & $\begin{array}{l}\text { Vineyards, } \\
\text { agricultural } \\
\text { lands }\end{array}$ & $\begin{array}{l}\text { Pastures, } \\
\text { natural } \\
\text { grassland }\end{array}$ & $\begin{array}{l}\text { Build areas, } \\
\text { rivers, bare } \\
\text { rocks }\end{array}$ \\
\hline $\begin{array}{l}\text { Profile curvature: } \\
13.18 \%\end{array}$ & & & $0.9-2.5$ & $0-0.9$ & $-2.5-0$ \\
\hline Soil texture: $11.75 \%$ & $\begin{array}{l}\text { Loamy-sandy, } \\
\text { sandy-loamy }\end{array}$ & $\begin{array}{l}\text { Loamy-sandy-- } \\
\text { loamy-clay, } \\
\text { loamy-sandy-loamy }\end{array}$ & $\begin{array}{l}\text { Loamy, varying } \\
\text { textures, loamy-- } \\
\text { loamy-clay }\end{array}$ & $\begin{array}{l}\text { Loamy-clay- } \\
\text { clay, loamy-clay }\end{array}$ & Clay \\
\hline $\mathrm{L}-\mathrm{S}$ factor: $11.75 \%$ & $0-1.5$ & $1.5-3$ & $3-4.5$ & $4.5-6$ & $>6$ \\
\hline Lithology: $5.45 \%$ & Loess deposits & Gravels, sands & Marls, clays & Conglomerates & $\begin{array}{l}\text { Sandstones, } \\
\text { shists, sandstone } \\
\text { of Răchitaşu }\end{array}$ \\
\hline $\begin{array}{l}\text { Rainfall intensity } \\
\text { (units MFI): } 10.95 \%\end{array}$ & $55-61$ & $61-67$ & $67-73$ & $73-79$ & $79-85$ \\
\hline $\begin{array}{l}\text { Convergence } \\
\text { index: } 5.45 \%\end{array}$ & $>0$ & $0-(1)$ & $(-1)-(-2)$ & $(-2)-(-3)$ & $<-3$ \\
\hline $\begin{array}{l}\text { Drainage density } \\
\left(\mathrm{km} / \mathrm{km}^{2}\right): 8.7 \%\end{array}$ & $<1.5$ & $1.5-3$ & $3-4.5$ & $4.5-6$ & $>6$ \\
\hline $\begin{array}{l}\text { Slope orientation: } \\
3.81 \%\end{array}$ & North, northeast & Northwest, east & Flat surfaces & West, southeast, & south, southwest \\
\hline Bonitation score & 1 & 2 & 3 & 4 & 5 \\
\hline FFPI (classes) & $11.5-18.7$ & $18.7-22$ & $22-25.5$ & $25.5-28.5$ & $28.5-37.1$ \\
\hline
\end{tabular}

and slope orientation (table 1). The morphometric parameters of the catchment and hydrographic network (slope, L-S factor, drainage density, network convergence, slope orientation) were derived from the Digital Elevation Model - DEM (SRTM, 30 m). The lythology was extracted from the Geological Digital Map of Romania 1:200,000 (Romanian National Geological Institute 1967). The land cover for the study, was extracted from the Corine Land Cover European database, 2006, while the soil texture was extracted from the Romanian Digital Pedological Map (National Institute for Research and Development for Pedology, Agrochemistry and Environmental Protecion 2002).

Rainfall intensity was estimated by means of the modified Fournier index (MFI) (equation 2), proposed by Arnoldus (1980), and used by Morgan (2005) and Kourgialas and Karatzas (2011):

$$
\mathrm{MFI}=\sum_{1}^{12} \frac{p^{2}}{P},
$$

where $\sum_{1}^{12}=$ the 12 -month summation, $p=$ the average monthly rainfall and $P=$ the average annual rainfall.

Average monthly multiannual rainfall data (for the 1962-2000 period), from 16 weather stations located in the study area's vicinity, were used in order to compute and mapping MFI in the Cernăteşti catchment. The Spline interpolation method was used in order to map MFI values, as it is considered to be the most appropriate for interpolation with a relatively small number of input points (Kourgialas and Karatzas 2011).

The slope and profile curvature ranking, needed for computing the FFPI (table 1), was based on relevant literature sources (Moţoc 1975; Minea 2012, 2013). Regarding slope orientation, it was considered that the ones favouring the occurrence of accelerated surface runoff are those generally south-exposed, as they favour a faster snowmelt process due to significant heating of the soil during winter, while during the summer season, due to the upward vertical thermal convection of water vapour-rich air, convective-type clouds occur, generating heavy rainfall (Prăvălie and Costache 2014). With regard to drainage density, the network convergence index, MFI and L-S factor, as the relevant literature does not provide any standardized classifications, equal intervals were considered for value classes. The classification and weighed ranking for the land cover factor were performed according to Manning's roughness coefficients which were assigned to each type of cover separately, as these values show the extent to which water runoff is favoured on different types of surfaces (Arcement and Schneider 1989), while the soil texture classification was based on assigning a soil hydrologic group to each type of texture (Chendeş 2011). Concerning the lithology, the classes were 
established taking into account the hardness of the rocks (Zăvoianu 1978).

In order to compute the FPI (table 2), eight variables were considered: land slope, land cover, soil texture, lithology, rainfall intensity (expressed by MFI), network convergence index, elevation (absolute) and elevation about channel. The network convergence index, elevations (absolute and above channel) and MFI were classified using the equal value interval method. The slopes were classified in the same way as FFPI, but in a reversed manner, in terms of weighed ranking marks: high slopes received low scores, while low slopes with high favourability for water stagnation and accumulation received high scores. With regard to lithology, land cover and soil texture, the same classification criteria were used as for the computation of FFPI.

The scores for each class were given depending on the degree of influence on surface runoff or water accumulation/flooding. Thus, the highest scores (5) were given to the classes with the highest influence on surface runoff (for FFPI) and water accumulation (for FFI).

Since the 10 factors used to determine FFPI and the eight used to determine FPI do not have the same influence on surface runoff and flooding, a weighing process was introduced. In order to assign different weights in the final equations of the two indices, the weight module of the IDRISI Selva software was used (Behera et al. 2012), which estimates the relative weight of each factor by comparing all factors, two by two. The method is based on an analytical hierarchy process (Sharma and Lees 2004).
The weight of each factor is shown in tables 1 and 2. The sum of the percentages attributed to the considered factors is $100 \%$. Final formulae for determining FFPI (3) and FPI (4) are structured as follows:

$$
\begin{aligned}
\mathrm{FFPI}= & 1.448 *(S+L C)+1.318 * P C \\
& +1.175 *(S t+L-S) \\
& +0.545 *(L i+C I)+1.095 * M F I \\
& +0.87 * D d+0.381 * A
\end{aligned}
$$

and

$$
\begin{aligned}
\mathrm{FPI}= & 1.69 * S+1.432 * L C+1.203 * S t \\
& +0.963 * L i+1.313 * E a c \\
& +1.317 * \mathrm{MFI}+1.03 * C I \\
& +1.061 * E
\end{aligned}
$$

where $L C=$ land cover; $S=$ land slope $\left(^{\circ}\right) ; P C=$ profile curvature; $S t=$ soil texture; $L-S=\mathrm{L}-\mathrm{S}$ factor; $L i=$ lithology; $C I=$ network convergence index; MFI $=$ modified Fournier index; $D d=$ drainage density $\left(\mathrm{km} / \mathrm{km}^{2}\right) ; A=$ aspect (slope orientation); $E=$ elevation $(\mathrm{m}) ; E a c=$ elevation above channel $(\mathrm{m})$.

The weighed summation of the reclassified factors was computed in the GIS environment and the results on FFPI and FFI were mapped at the

\begin{tabular}{|c|c|c|c|c|c|}
\hline \multicolumn{3}{|l|}{ Parameters/wieght (\%) } & \multicolumn{3}{|l|}{ Types/values } \\
\hline Slope $\left({ }^{\circ}\right): 16.9 \%$ & $>30$ & $20-30$ & $10-20$ & $5-10$ & $0-5$ \\
\hline $\begin{array}{l}\text { Land cover/use: } \\
14.23 \%\end{array}$ & $\begin{array}{l}\text { Decidous forest, } \\
\text { coniferous forest, } \\
\text { mixed forest }\end{array}$ & $\begin{array}{l}\text { Orchards, transitional } \\
\text { woodland-shrub, } \\
\text { beaches, dunes }\end{array}$ & $\begin{array}{l}\text { Vineyards, } \\
\text { agricultural lands }\end{array}$ & $\begin{array}{l}\text { Pastures, } \\
\text { natural grassland }\end{array}$ & $\begin{array}{l}\text { Build areas, } \\
\text { rivers, bare rocks }\end{array}$ \\
\hline Soil texture: $12.03 \%$ & $\begin{array}{l}\text { Loamy-sandy, } \\
\text { sandy-loamy }\end{array}$ & $\begin{array}{l}\text { Loamy-sandy-- } \\
\text { loamy-clay, } \\
\text { loamy-sandy-loamy }\end{array}$ & $\begin{array}{l}\text { Loamy, varying } \\
\text { textures, loamy- } \\
\text { loamy-clay }\end{array}$ & $\begin{array}{l}\text { Loamy-clay- } \\
\text { clay, loamy-clay }\end{array}$ & Clay \\
\hline Lithology: $9.63 \%$ & Loess deposits & Gravels, sands & Marls, clays & Conglomerates & $\begin{array}{l}\text { Sandstones, shists, } \\
\text { sandstone of } \\
\text { Răchitaşu }\end{array}$ \\
\hline $\begin{array}{l}\text { Rainfall intensity } \\
\text { (units MFI): } 13.17 \%\end{array}$ & $55-61$ & $61-67$ & $67-73$ & $73-79$ & $79-85$ \\
\hline $\begin{array}{l}\text { Convergence index: } \\
10.30 \%\end{array}$ & $>0$ & $0-(1)$ & $(-1)-(-2)$ & $(-2)-(-3)$ & $<-3$ \\
\hline Elevation (m): $10.61 \%$ & $1106-1353$ & $859-1106$ & $613-859$ & $366-613$ & $119-366$ \\
\hline $\begin{array}{l}\text { Elevation above } \\
\text { channel (m): } 13.13 \%\end{array}$ & $>4$ & $3.1-4$ & $2.1-3$ & $1.1-2$ & $0-1$ \\
\hline Bonitation score & 1 & 2 & 3 & 4 & 5 \\
\hline FPI (classes) & $15.2-23.7$ & $23.7-27.1$ & $27.1-30.5$ & $30.5-35.3$ & $35.3-45.3$ \\
\hline
\end{tabular}
Slănic catchment spatial scale.

In order to delineate the flood prone-areas and assess the structural vulnerability for flood peaks with different exceedance probabilities, 1D hydraulic simulation was performed using the HEC-RAS 4.1 hydraulic model. It was developed

Table 2. Weighting and classification of geographical factors for determining the FPI index in the Slănic catchment. 
by the US Army Corps of Engineers (USACE 1993); for easier input data processing and generation, as well as for improved result rendering, the same institution created the HEC-GeoRAS extension, which connects the hydraulic modelling software with ArcGIS. The ArcGIS 10.1 software HEC-GeoRAS 10 extension was used in order to obtain riverbed geometry input data, which connects the HEC-RAS 4.1 model with the GIS software.

The modelling process was conducted in two main stages. The first consisted in the GIS rendering of Slănic's channel geometry, with the help of the HEC-GeoRAS 10 extension: thalweg line, left bank, right bank and 24 cross-sections (figure 2b) with $100 \mathrm{~m}$ equidistance (figure 2c). Channel elements and their properties (length, width, elevation, spatial references) were derived from DEM, with $0.5 \mathrm{~m}$ sized cell. The model was obtained by level curve interpolation (2.5 m equidistance), extracted from a 1:5000 topographic map and a total of 110 elevation points recorded with a GPS Trimble GeoXH unit (10 $\mathrm{cm}$ vertical and horizontal accuracy) in Slănic's riverbed, within the Cernăteşti commune (figure 2a). The DEM was processed before being used as a source for extracting riverbed geometry elements used in the hydraulic modelling. Thus, in order to fill the micro-depressions of the DEM surface, the Fill tool of the hydrology module of the spatial analyst extension of ArcGIS 10.1 software was used, while the elimination of positive micro-landforms (sinks) was performed with the Sink tool of the same module of ArcGIS 10.1 software. Once the channel geometry was converted in shp. vector format, it was exported from ArcGIS 10.1 in sdf. format, which is compatible with the HEC-RAS 4.1 hydraulic modelling software.

In the second stage, flood-prone areas were simulated by steady flow hydraulic modelling, for flood peaks with exceedance probabilities of $1 \%$, $5 \%$ and $10 \%$. Steady-flow hydraulic modelling was used because this study entailed a modelling process which was applied to singular flow data corresponding to the three exceedance probabilities, which do not take time into account, as opposed to unsteady flow modelling, which takes the temporal component into account (and the input data will consist in a flash flood hydrograph).

Thus, once the channel geometry was exported from ArcGIS 10.1 in sdf. format, the specificities (thalweg, the two banks and cross-sections) were imported into the HEC-RAS model. The model was subsequently calibrated by introducing Manning's roughness coefficients (Remo et al. 2009) for each intersection point of the 24 cross-sections with the river thalweg and the two banks. Manning coefficient values generally vary depending on land use types. In the case of riverbeds, coefficient oscillations are due to the nature of riverbed sediment, the presence of micro-landforms (dunes, islands) and meanders (USACE 1993; Dyhouse et al. 2003; Remo et al. 2009). Given the short length (approximately $2.5 \mathrm{~km}$ ) and surface characteristics homogeneity of the Slănic minor riverbed sector covered by the simulation, the Manning coefficient values ranged from 0.035 for the two banks to 0.04 for the thalweg (HEC-RAS 4.1 User Manual).

In the calibration stage, the general river slope of about $5 \mathrm{~m} / \mathrm{km}$ was introduced as a reach boundary condition. Flood peaks corresponding to the $1 \%$, $2 \%$ and $10 \%$ exceedance probabilities were subsequently added, and the flood-prone area simulation mapping was initialized. The GIS HEC-RAS MAPPER extension of the HEC-RAS 4.1 software was used for obtaining a plane view section of flood risk zone changes.

Finally, structural elements (roads, buildings and annexes) that could be affected by flooding were identified by overlapping the resulting flood-prone areas and vectorized data from a 2008 orthophotomap.

\section{Results}

\subsection{Flood magnitude and frequency}

The annual flood peaks of the Slănic River, at Cernăteşti hydrometric station, had a high variability: between 1970 and 2010, they oscillated between $7.66 \mathrm{~m}^{3} / \mathrm{s}(1987)$ and $410 \mathrm{~m}^{3} / \mathrm{s}$ (1975) (figure 3a), with an annual coefficient of variation $(\mathrm{Cv})$ of 1.1 . The highest floods were recorded in $1975\left(410 \mathrm{~m}^{3} / \mathrm{s}\right.$, in July), $1991\left(270 \mathrm{~m}^{3} / \mathrm{s}\right.$, in July), $1970\left(252 \mathrm{~m}^{3} / \mathrm{s}\right.$, in August), $1996\left(219 \mathrm{~m}^{3} / \mathrm{s}\right.$, in September) and $2005\left(122 \mathrm{~m}^{3} / \mathrm{s}\right.$, in July).

As there is no major anthropic impact (dams and reservoirs, intakes), this flood peak variability is mostly conditioned by climatic factors, and is mainly rainfall-related. Most annual floods (51\%) occurred in summer, due to heavy rains. Nearly a quarter of the annual floods occurred in spring, as a consequence of the rich water supply resulting from precipitations and snowmelt. Autumn has the smallest annual flood share $(7 \%)$, while winter accounts for the remaining $17 \%$. The months with the highest flood potential are July, June and May, when $22 \%, 17 \%$ and $15 \%$ respectively of the annual floods occurred (figure 3b).

No statistically significant linear trend was identified in the annual flood peak variability (according to the Mann-Kendall test), although a slight downward trend can be distinguished graphically (figure 3a). A certain cyclicality can be noticed, evinced by the fifth degree polynomial trend which 


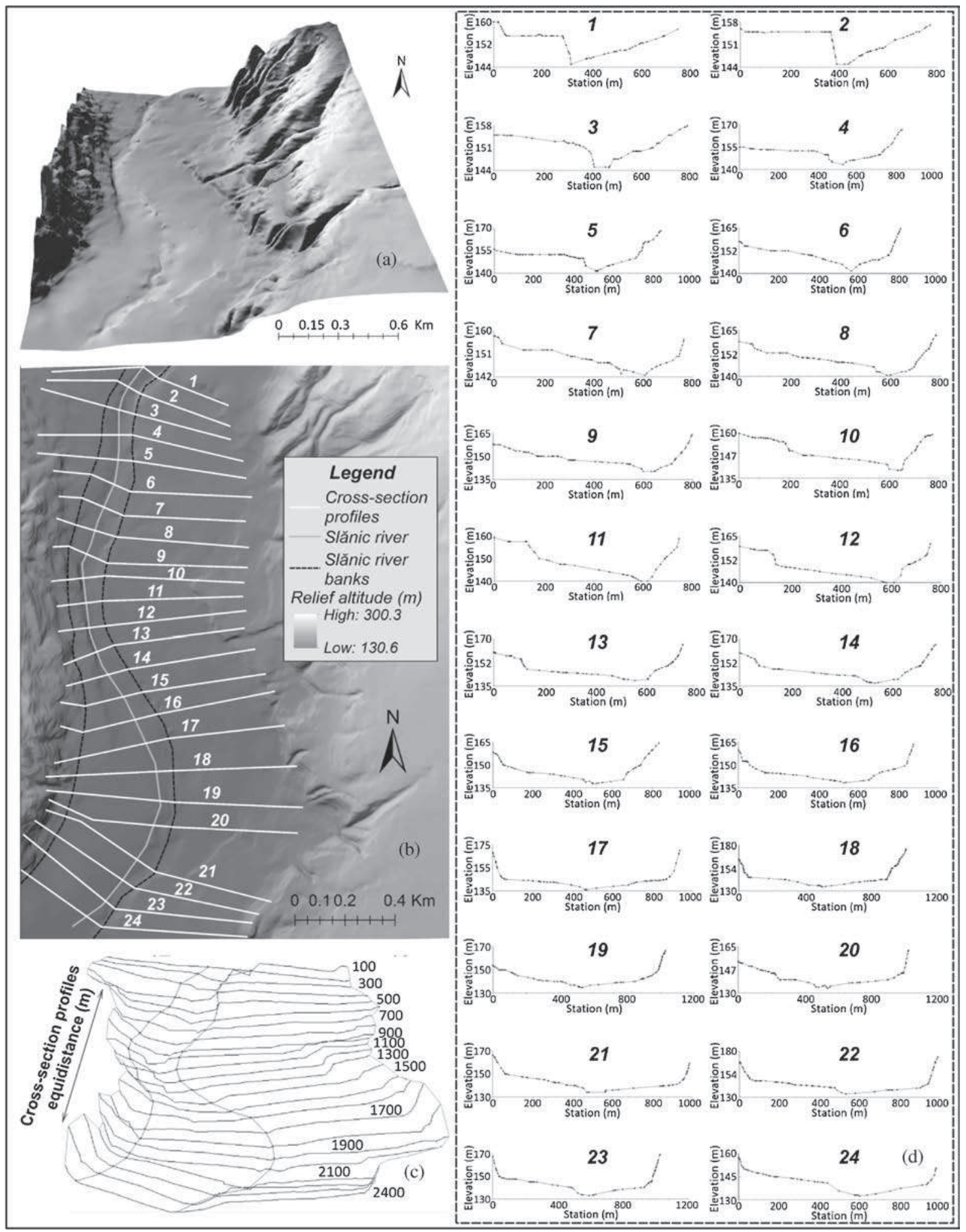

Figure 2. Digital elevation model (1:3 vertical exaggeration) (a) and 100 m equidistant cross-sections (b, c, d), used for delimiting flood-prone areas within the Cernăteşti settlement.

reveals alternating periods of high (1970-1977, 1991-1999) and low flow (1978-1990, 2000-2010) (figure 3a). This cyclicality is also shown by the decennial analysis of major floods (with peaks higher than the average of the maximum annual discharges recorded during 1970-2010), maximum and average of annual flood peaks. Most of the major floods (11) occurred in the 1990-1999 decade, when the maximum flood peak was 270 $\mathrm{m}^{3} / \mathrm{s}$, and the average of maximum flow was 106 

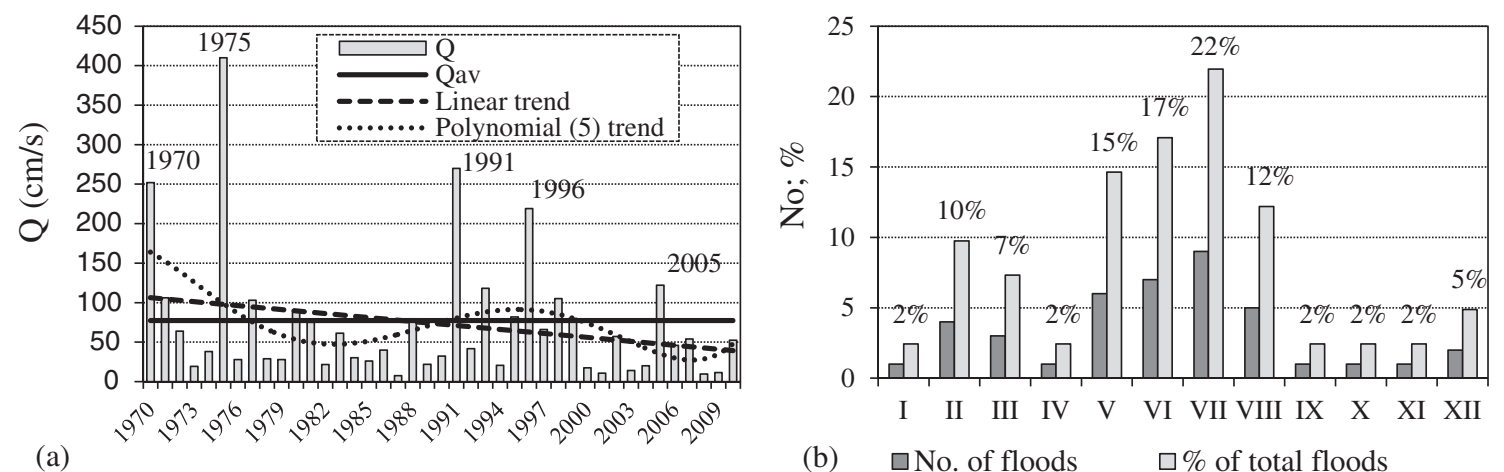

(b) $\square$ No. of floods $\square \%$ of total floods

Figure 3. Annual flood peak variability, linear and polynomial trend lines (a) and monthly frequencies of annual floods (b) on Slănic River, at Cernăteşti hydrometric station $(\mathrm{Q}=$ annual maximum discharge; Qav = average of annual maximum discharge).

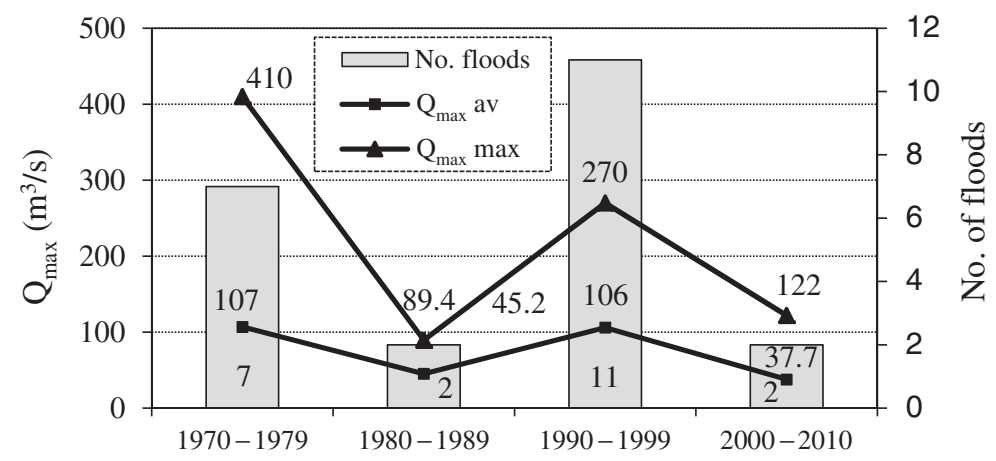

Figure 4. Decennial variability of average of annual maximum flow ( $Q_{\max }$ av), maximum of annual flood peaks (Qmax max) and number of major floods (with the peak $>$ Qmax av).

Table 3. Specificities of the flood waves with highest magnitudes (peak above $100 \mathrm{~m}^{3} / \mathrm{s}$ ) recorded at the Cernăteşti gauging station, on Slănic River (between 1970 and 2010).

\begin{tabular}{lcrrrrl}
\hline Date & $\begin{array}{c}\text { Qmax } \\
\left(\mathrm{m}^{3} / \mathrm{s}\right)\end{array}$ & $\begin{array}{c}\text { Wt } \\
\left(\text { millions } \mathrm{m}^{3}\right)\end{array}$ & $\begin{array}{c}\mathrm{H} \\
(\mathrm{mm})\end{array}$ & $\begin{array}{c}\mathrm{Tc} \\
(\mathrm{hr})\end{array}$ & $\begin{array}{c}\mathrm{Ts} \\
(\mathrm{hr})\end{array}$ & $\begin{array}{c}\mathrm{Tt} \\
(\mathrm{hr})\end{array}$ \\
\hline $7 / 3 / 1975$ & 410 & 12.0 & 29.1 & 8 & 30 & 38 \\
$6 / 30 / 1991$ & 270 & 9.5 & 22.8 & 7 & 40 & 47 \\
$7 / 29 / 1991$ & 270 & 4.1 & 9.9 & 3.75 & 15.75 & 19.5 \\
$8 / 25 / 1970$ & 252 & 10.5 & 25.3 & 14 & 24 & 38 \\
$9 / 24 / 1996$ & 219 & 6.4 & 15.5 & 5 & 16 & 21 \\
$7 / 13 / 2005$ & 122 & 3.7 & 8.9 & 4.5 & 8 & 12.5 \\
$7 / 2 / 1971$ & 106 & 4.7 & 11.3 & 31 & 41 & 72 \\
$1 / 21 / 1998$ & 105 & 5.2 & 12.5 & 26 & 22 & 48 \\
$6 / 14 / 1977$ & 103 & 2.5 & 6.1 & 8.5 & 14 & 22.5 \\
Average & & 6.5 & 15.7 & 12.0 & 23.4 & 35.4 \\
\hline
\end{tabular}

$\mathrm{m}^{3}$ /s (figure 4). In the 1970-1979 decade, the number of major floods was slightly lower (7), but the maximum flood peak reached the highest value in the analysed period $\left(410 \mathrm{~m}^{3} / \mathrm{s}\right)$. The $1980-1989$ and 2000-2010 decades totalled a small number of major floods (2) and maximum flood peaks reached 89 and $122 \mathrm{~m}^{3} / \mathrm{s}$, respectively, with an average of maximum flow below $50 \mathrm{~m}^{3} / \mathrm{s}$.

The analysis (performed using the Cavis model) of the floods with highest magnitudes (flood peaks

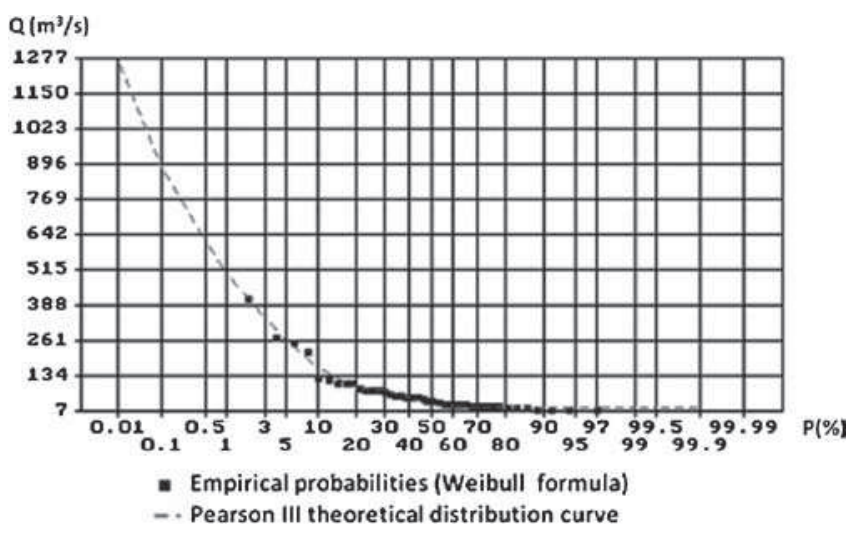

Figure 5. Pearson type III distribution curve and empirical exceedance probabilities for annual flood peaks of Slanic river at Cernăteşti gauging station (1970-2010).

above $100 \mathrm{~m}^{3} / \mathrm{s}$ ) recorded at the Cernăteşti gauging station (1970-2010) shows that floods are generally fast, with average rising time of $12 \mathrm{hr}$ and average total time of $35.4 \mathrm{hr}$, which makes them potentially destructive, as confirmed by frequent damages caused to the transport infrastructure and bridges. The time to peak ranged from $4.5-5 \mathrm{hr}$ (floods in 1996 and 2005) to $31 \mathrm{hr}$ (1971 flood), and total times from $12.5 \mathrm{hr}$ (in 2005) to $72 \mathrm{hr}$ (in 1971). The total volume of the most important 


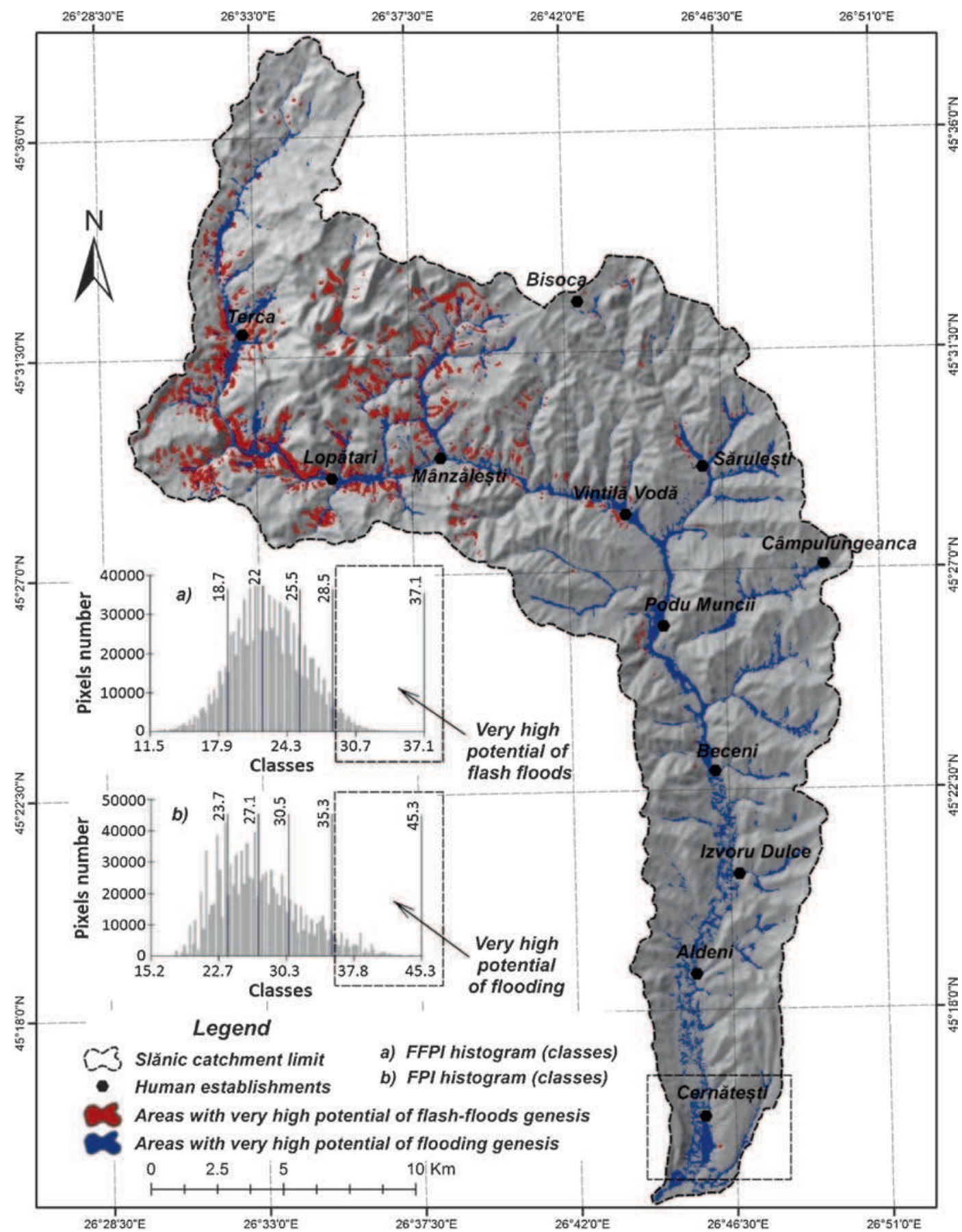

Figure 6. Areas with high flash-flood and flooding potential in the Slănic catchment.

floods varied, depending on flood peak and durations, between 12 (in 1975) and 2.5 million $\mathrm{m}^{3}$ (in 1977), with average maximum volume of 6.5 million $\mathrm{m}^{3}$. The aforementioned volumes are equivalent to a water depth of $29.1 \mathrm{~mm}$ (maximum), $6.1 \mathrm{~mm}$ (minimum) and $15.7 \mathrm{~mm}$ (average value) (table 3).

The discharges with different exceeding probabilities used for flood-prone area mapping were obtained based on the frequency analysis of annual flood peaks between 1970 and 2010 at the Cernăteşti gauging station. To this end, the
Pearson type III distribution was used, which is adapted to Romanian territory (NIHWM 1997; Stănescu and Drobot 2002; Zaharia 2002). The exceedance probabilities (P\%) of $1 \%, 5 \%$ and $10 \%$, corresponding to return periods of 100, 20 and 10 years respectively, were considered. The discharges with different probabilities were obtained using NIHWM's ASIG software (National Institute of Hydrology and Water Mangement), computing version 3, wherein Cscor/Cvcor $=2.88$ (Cscor $=$ corrected coefficient of skew and Cvcor $=$ corrected coefficient of variation). In this computing version, 


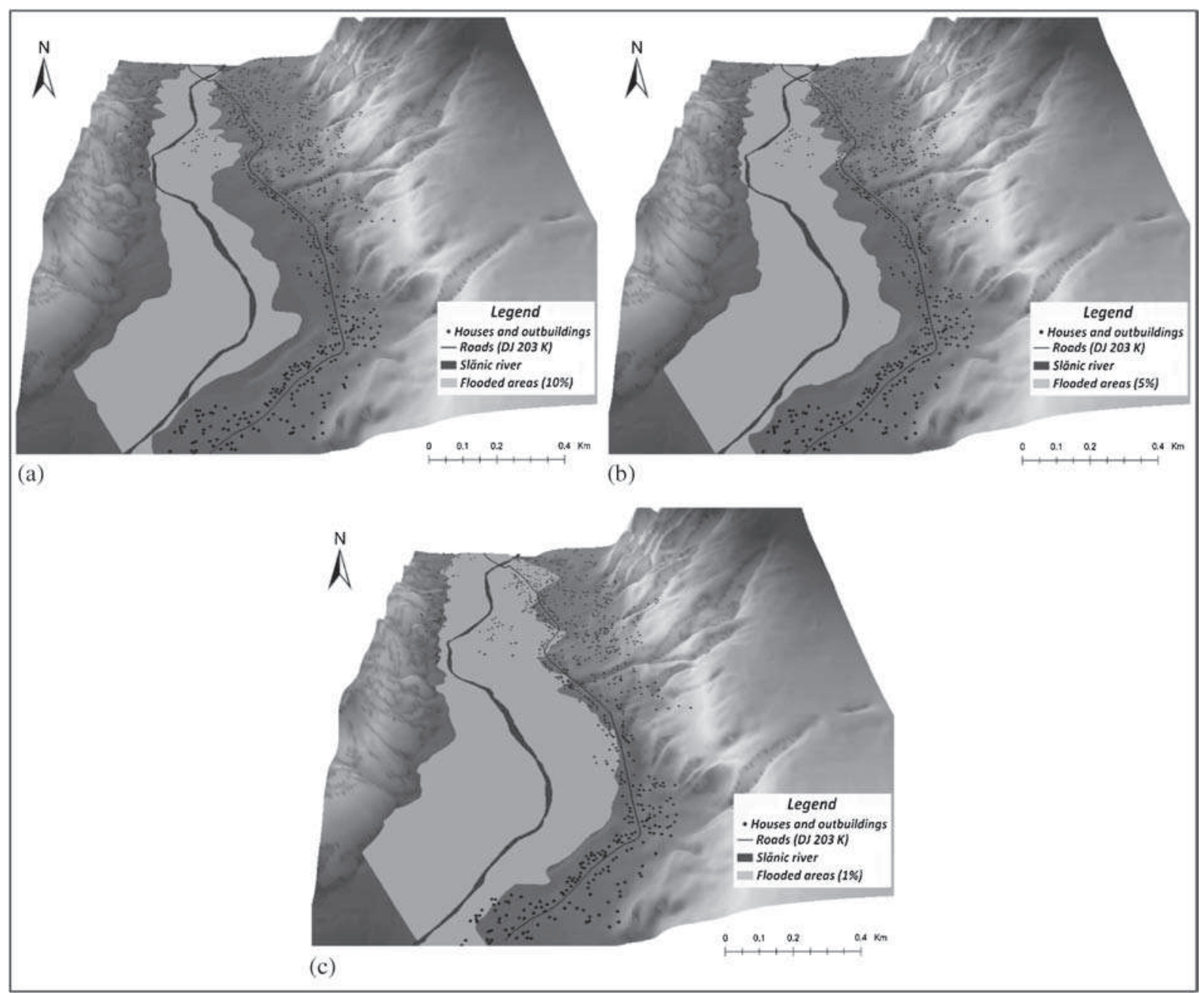

Figure 7. Simulated flooded areas in case of flood peaks with exceedance probabilities of $10 \%$ (a), $5 \%$ (b) and $1 \%$ (c) in Cernăteşti village.

the root-mean-square error (RMSE), which expresses the difference between the values estimated by Pearson type III distribution and the ones estimated based on the empirical curve (using the Weibull formula), has the lowest values, and the theoretical curve best fits empirical probabilities determined based on the measured values (figure 5). The flood peaks for the three probabilities are: $507 \mathrm{~m}^{3} / \mathrm{s}$ for $\mathrm{P} 1 \%, 263 \mathrm{~m}^{3} / \mathrm{s}$ for $\mathrm{P} 5 \%$, and $169 \mathrm{~m}^{3} / \mathrm{s}$ for $\mathrm{P} 10 \%$.

\subsection{Flood and flooding potential assessment}

In order to identify areas with high potential for floods and flooding occurrence within the Slănic catchment, the FFPI and FPI were computed and mapped, as mentioned in Methodology.

The obtained values of FFPI range from 11.5 to 37.1. Using the Natural Breaks classification method, the FFPI values were grouped into five classes. The first two comprise areas with low and very low potential for accelerated surface runoff, while the third class refers to areas with moderate potential. The values from 28.57 to 37.1 , which form the fifth FFPI class, describe areas with a very high potential for accelerated runoff and consequently, for flash-flood genesis. Such areas are generally present on steep, deforested slopes in the middle and upper catchment sectors.

The class with the highest index values is mapped in figure 6, indicating areas with high potential for flash-flood genesis (FFPI) and flooding (FPI). These areas cover approximately 19.35 $\mathrm{km}^{2}$, which is about $4.53 \%$ of the Slănic catchment.

The FPI values, expressing the flooding potential, range from 15.2 to 45.3 and were grouped into five classes, using the Natural Breaks method. The first two characterize areas with low potential for water accumulation and stagnation. Generally, such surfaces are present in areas with high slopes, and soil textures and lithologic substratum that allow water infiltration. Very high FPI values fall between 35.3 and 45.3. Such values are found in $6.48 \%\left(27.7 \mathrm{~km}^{2}\right)$ of the Slănic River catchment, 
and are mainly present in floodplain areas, especially along the Slănic River (figure 6). These areas generally have slopes below $3^{\circ}$ and a high impermeability due to the built area. As such, the settlements located along the Slănic River have a high exposure to flooding.

The overall spatial distribution of high FFPI and FPI values (figure 6) makes the causal relationship between them apparent: the high potential for accelerated surface runoff and flash-flood formation of the upper catchment favours flooding in the lower sector, by upstream-downstream flow propagation.

\subsection{Flood-prone areas and structural vulnerability assessment}

As shown in figure 6, Cernăteşti settlement is situated in an area with high flooding potential. By using the HEC-RAS 4.1 hydraulic model, the floodprone areas for flood peaks of the Slănic River (at Cernăteşti gauging station) with exceedance probabilities of $1 \%, 5 \%$ and $10 \%$ were mapped (figure 7).

For a flood peak of $10 \%$ exceedance probability (corresponding to $169 \mathrm{~m}^{3} / \mathrm{s}$ ), the simulated flooded area covers an area of 78 ha (figure $7 \mathrm{a}$ ). The lateral expansion of the southern sector is particularly noticeable. The configuration of the cross-sections drawn perpendicularly on the Slănic River shows channel width increases in the northern sector, where the riverbed is bordered by a steep, high bank. This explains the flooded area's configuration in the analysed sector.

In the case of a flood peak of $10 \%$ exceedance probability, the 78 ha water-covered hectares would flood 21 houses and household annexes, located in the centre of the study area (figure 7a). In this scenario, $1850 \mathrm{~m}$ of local and county roads would be covered by water. For a flood peak with a 20year return period, the flooded area would cover 91 hectares, affecting 34 buildings and about $2500 \mathrm{~m}$ of roads (figure $7 \mathrm{~b}$ ). In the event of a flood with a peak with 100 years return period, the water would cover 120 ha, flooding 178 buildings and about 4400 $\mathrm{km}$ of local roads (figure $7 \mathrm{c}$ ).

\section{Conclusions}

Due to major annual flood-related damages, the assessment and management of flood risks is a major priority, from global to regional and local scale. Flood risk-related political, financial and technical decisions require thorough mappingbased studies and analyses at different spatial scales, in order to identify flood prone areas and estimate their vulnerability, so that the most effective risk mitigation measures can be enforced.

This paper aimed to assess and map the flood and flooding potential at different spatial scales (from the catchment to a local scale) in order to identify areas exposed to flash-floods and flooding and estimate their vulnerability. To this end, three main methods were used in the Slănic River catchment: (i) statistical analyses, (ii) computation and mapping of flash-flood/flooding potential indices, and (iii) hydraulic modelling. These methods helped in (i) the analysis of the Slănic River floods specificities (magnitude, frequency and flood waves features), (ii) the identification of areas with high flash-flood and flooding potential in the Slănic catchment, and (iii) flood-prone areas delineation and the structural vulnerability assessment in Cernăteşti settlement. Although the results may be influenced by certain errors and uncertainties (associated to data quality, methods, spatial resolutions, etc.), they can improve the understanding of floods and flooding specificities in Cernăteşti village, as well as in the entire Slănic's catchment, in view of effectively managing flood-related risks.

We consider that the results of this study may serve to supplement the information found in the Preliminary Assessment of Flood Risk (EPRI) report on the Ialomița-Buzău hydrographic district (execution deadline - December 2011; reporting to the European Commission deadline - March 2012), according to which the rivers in Slănic catchment have no significant potential flood risk (BIWB 2013). Such reports were made using a unitary methodology (mainly based on analysing flood and damage history and estimating future potential damages) in all of Romania's hydrographic districts, as part of the first stage of implementation of European Directive 2007/60/EC on the assessment and management of flood risks. Since EPRI reports have relatively rough spatial resolutions, results of smaller spatial scale studies, such as the ones in the present paper, can be relevant due to the more detailed information they contain, which can be used for improving the flood risk management at local scale.

\section{Acknowledgements}

The author, Costache Romulus, would like to specify that this paper has been financially supported within the project entitled "SOCERT. Knowledge society, dynamism through research", contract number POSDRU/159/1.5/S/132406. This project is co-financed by European Social Fund through Sectoral Operational Programme for Human Resources Development 2007-2013 - Investing in people! 


\section{References}

Alexandrescu M I 2010 Gestiunea cantitativa a resurselor de apă in bazinul hidrografic Ialomiţa, Doctoral Thesis, Construction Technical University, Bucharest.

Anderson K C and Neff T 2011 The influence of paleofloods on archaeological settlement patterns during AD 10501170 along the Colorado River in the Grand Canyon, Arizona, USA; Catena 85 168-186.

Arcement Jr G J and Schneider V R 1989 Guide for selecting Manning's roughness coefficients for natural channels and flood plains; United States Geological Survey Water-supply Paper 2339, pubs.usgs.gov/wsp/2339/ report.pdf.

Armaş I, Nistoran D E, Osaci-Costache G and Braşoveanu L 2012 Morpho-dynamic evolution patterns of subCarpathian Prahova River (Romania); Catena 10083 99.

Arnoldus H M J 1980 An approximation of the rainfall factor in the universal soil loss equation, In: Assessment of Erosion (eds) De Boodt and Gabriels D, Wiley, New York, pp 127-132.

Behera M D, Borate S, Panda S, Behera P and Roy P 2012 Modelling and analyzing the watershed dynamics using Cellular Automata (CA)-Markov model - A geoinformation based approach; J. Earth Syst. Sci. 121(4) 1011-1024.

Below R, Wirtz A and Guha-Sapir D 2009 Disaster category classification and peril terminology for operational purposes, Université Catholique de Louvain, 20p. http:// cred.be/sites/default/files/DisCatClass_264.pdf.

BIWB 2013 Raport - Evaluarea preliminara a riscului la inundatii (EPRI), http://www.rowater.ro/EPRI\%20 Rapoarte/RO5_\%20PFRA_Report_\%2020130531.pdf.

Brazdil R, Kundzewiczz W and Benito G 2006 Historical hydrology for studying flood risk in Europe; Hydrol. Sci. J. 51(5) 739-764.

Bryant R G and Rainey M P 2002 Investigation of flood inundation on playas within the zone of Chotts, using a time-series of AVHRR; Remote Sens. Environ. 82(2/3) $360-375$.

Cesur D 2007 GIS as an information technology framework for water modeling; J. Hydroinform. 9(2) 123-134.

Chendeş V 2011 Water resources within curvature subCarpathians. Geospatial assessments; Romanian Academy Publisher, Bucharest, 339p.

CLC 2006 Corine Land Cover. European Environment Agency, www.eea.europa.eu.

Costache R 2014 Using GIS techniques for assessing lag time and concentration time in small river basins. Case study: Pecineaga river basin, Romania; Geographia Technica 9(1) $31-38$.

Costache R and Prăvălie R 2012 The use of GIS techniques in the evaluation of the susceptibility of the floods genesis in the hydrographical basin of Bâsca Chiojdului river; Analele Universitătii din Oradea - Seria Geografie 32(2) 284-293.

Costache R and Prăvălie R 2013 The analysis of 29 May 2012 flood phenomena in the lower sector of Slănic drainage basin (case of Cernăteşti locality area); GEOREVIEW - Analele Universitătii Ştefan cel Mare Suceava, Seria Geografie 22(1) 78-87.

Costache R, Prăvălie R, Mitof I and Popescu C 2015 Flood vulnerability assessment in the low sector of Sărăţel catchment. Case study: Joseni village; Carpathian J. Earth Environ. Sci. 10(1) 161-169.

Daraio J A, Weber L J, Newton T J and Nestler J M 2010 A methodological framework for integrating computational fluid dynamics and ecological models applied to juvenile freshwater mussel dispersal in the upper Mississippi River; Ecol. Model. 221 201-214.

DEPC 2007 Directive 2007/60/EC of the European Parliament and of the Council of 23 October 2007 on the assessment and management of flood risks; Official Journal of the European Union $L$ 288(27) 8p. http://eur-lex.europa.eu/LexUriServ/LexUriServ.do?uri= OJ:L:2007:288:0027:0034:en:pdf.

Devon M B 2003 Hydraulic modelling of Athabasca Vallis, Mars; Hydrol. Sci. J. 48(4) 655-664.

Di Baldassare G and Ciaps P 2011 A hydraulic study on the applicability of flood rating curves; Hydrol. Res. 42(1) $10-19$.

DHI 2009 A modelling system for rivers and channels - Mike 11 Reference Manual.

Dolcine L, Andrieu H, Sempere-Torres D and Creutin D 2001 Flash flood forecasting with coupled precipitation model in mountainous Mediterranean basin; J. Hydrol. Eng. 6(1) 1-10.

Dutta D, Herath S and Musiake K 2000 Flood inundation simulation in a river basin using a physically based distributed hydrologic model; Hydrol. Process. 14(3) 497-519.

Dyhouse G, Hatchett J and Benn J 2003 Floodplain modeling using HEC-RAS; Haestad Press, Waterbury, CT.

EM-DAT 2013 The OFDA/CRED International Disaster Database, www.emdat.be - Université catholique de Louvain - Brussels-Belgium, http://www.emdat.be/ result-country-profile (7.12 2013).

Fontanine I and Costache R 2013 Using GIS techniques for surface runoff potential analysis in the sub-Carpathian area between Buzău and Slănic rivers, in Romania; Cinq Continents 3(1) 201-214.

Grecu F, Zăvoianu I, Zaharia L and Comănescu L 2007 Analyse quantitative du réseau hydrographique du bassin versant du Slanic (Roumanie), Physio-Géo-Géographie Physique et Environnement, nr. 1, 79-93, ISSN: 1958573X, http://physio-geo.revues.org/1051.

Guha-Sapir D, Hoyois P and Below R 2013 Annual disaster statistical review 2012: The numbers and trends. Brussels: CRED; 2013, 50p, http://www.cred.be/sites/ default/files/ADSR_2012.pdf.

Haliuc A and Frantiuc A 2012 A study case of Baranca drainage basin flash-floods using the hydrological model of HEC-RAS; Analele Universităţii Ştefan cel Mare Suceava, Seria Geografie 21(1) 118-133.

Hudson P F and Colditz R R 2003 Flood delineation in a large and complex alluvial valley, lower Panuco basin, Mexico; J. Hydrol. 280 229-245.

Ion-Bordei N 1988 Fenomene meteo-climatice induse de configuratia Carpatilor in Campia Romana; Romanian Academy Publishing House, 175p.

Knebl M R, Yang Z-L, Hutchison K and Maidment D R 2005 Regional scale flood modeling NEXRAD rainfall, GIS, and HEC-HMS/RAS: A case study for San Antonia River Basin Summer 2002 storm event; J. Environ. Manag. 75 325-336.

Kourgialas N N and Karatzas G P 2011 Flood management and a GIS modelling method to assess flood-hazard areas - a case study; Hydrol. Sci. J. 56(2) 212-225.

Koutroulis A G and Tsanis I K 2010 A method for estimating flash flood peak discharge in a poorly gauged basin: Case study for the 13-14 January 1994 flood, Giofiros basin, Crete, Greece; J. Hydrol. 385 150-164.

Kundzewicz Z W, Pińskwar I and Brakenridge G R 2014 Large floods in Europe, 1985-2009; Hydrol. Sci J. 58(1) 1-7, doi: 10.1080/02626667.2012.745082.

Magirl C S, Breedlove M J, Webb R H and Griffiths P G 2008 Modeling water-surface elevations and virtual shorelines for the Colorado river in Grand Canyon, Arizona; U.S. 
Geological Survey Scientific Investigations Report 2008$5075,32 \mathrm{p}$.

Minea G 2012 Basca river catchment - Hydrogeographical study; Univesity of Bucharest Publisher, ISBN-978-60616-0134-9, 270p (in Romanian).

Minea G 2013 Assessment of the flash-flood potential of Basca River catchment (Romania) based on physiographic factors; Central European J. Geosci. 5(3) 344353.

Morgan R P C 2005 Soil Erosion and Conservation; Blackwell Publishing Ltd, Oxford.

Moțoc M 1975 Soil erosion and control methods; Ceres Publisher, Bucharest (in Romanian).

Mustăţea A 2005 Viituri excepţionale pe teritoriul României. ONESTA.COM PROD 94, 409p.

National Institute for Research and Development for Pedology, Agrochemistry and Environmental Protection 2002, Digital pedological map of Romania, scale: 1:200,000.

NIHWM 1997 Instruction for maximum discharge estimation in large catchments, Bucharest, 53p.

Papadimitrakisi A and Orphanos I 2009 Statistical analysis of river characteristics (in Greece): Basic hydraulic parameters; Hydrol. Sci. J. 54(6) 1035-1052.

Prăvălie R and Costache R 2013 The vulnerability of the territorial-administrative units to the hydrological phenomena of risk (flash-floods). Case study: The sub-Carpathian sector of Buzău catchment; Analele Universităţi din Oradea - Seria Geografie 23(1) 9198.

Prăvălie R and Costache R 2014 The analysis of the susceptibility of the flash-floods' genesis in the area of the hydrographical basin of Bâsca Chiojdului river; Forum Geografic 13(1) 39-49.

Remo J W F, Pinter N and Heine R 2009 The use of retro- and scenario-modeling to assess effects of $100+$ years river of engineering and land-cover change on Middle and lower Mississippi River flood stages; J. Hydrol. $376403-416$.

Romanian National Institute of Geology 1967 Geological map of Romania, scale: 1:200,000.

Roo A D, Barredo J, Lavalle C, Bodis K and Bonk Rado 2007 Potential flood hazard and risk mapping at PanEuropean scale; In: Digital terrain modelling development and applications in a policy support environment (eds) Peckham R J and Jordan G, Springer-Berlin, Heidelberg, Berlin, pp. 183-202.

Saleh F, Ducharme A, Flipo N, Oudin L and Ledoux E 2013 Impact of river bed morphology on discharge and water levels simulated by a 1D Saint-Venant hydraulic model at regional scale; J. Hydrol. 476 169-177.

Salmi T, Määttä A, Anttila P, Ruoho-Airola T and Amnell T 2002 Detecting trends of annual values of atmospheric pollutants by the Mann-Kendall test and Sen's slope estimates - The Excel template application MAKESENS. ISBN 951-697-563-1, Finnish Meteorological Institute, Helsinki, Finland.

Shaban A, Khawlie M, Bou Kheir R and Abdallah C 2001 Assessment of road instability along a typical mountainous road using GIS and aerial photos, Lebanoneastern Mediterranean; Bull. Eng. Geol. Environ. 60(2) 93-101.

Shaban A, Khawlie M and Abdallah C 2006 Use of remote sensing and GIS to determine recharge potential zones: The case of Occidental Lebanon; Hydrogeol. J. 14(4) 433-443.

Sharma S K and Lees B G 2004 A comparison of simulated annealing and Gis based Molafor solving the problem of multi-objective land use assessment and allocation; In: Proceedings of the 17th International Conference on Multiple Criteria Decision Analysis, Whistler, Canada, Open-File Report AP58.

Sheng Y, Gong P and Xiao Q 2001 Quantitative dynamic flood monitoring with NOAA AVHRR; Int. J. Remote Sens. 22(9) 1709-1724.

Smith G 2003 Flash flood potential: Determining the hydrologic response of FFMP basins to heavy rain by analyzing their physiographic characteristics. A white paper available from the NWS Colorado Basin River Forecast Center web site at http://www.cbrfc.noaa.gov/papers/ffp_wpap. pdf, $11 p$.

Stănescu V A and Drobot A 2002 Măsuri nestructurale de gestiune a inundatiilor, H.G.A. Publishing House, Bucharest, 341p.

Teodor S and Mătreaţă S 2011 A way of determining how small river basins of some rivers are susceptible to flashfloods; Carpathian J. Earth Environ. Sci. 6(1) 89-98.

Townsend P A and Walsh S J 1998 Modeling floodplain inundation using an integrated GIS with radar and optical remote sensing; Geomorphology 21 295-312.

UNISDR 2009 Terminology on Disaster Risk Reduction, United Nations International Strategy for Disaster Reduction, Geneva, 35p.

USACE 1993 River Hydraulics; US Army Corps of Engineers, Washington DC.

Wyrick J R, Rischman B A, Burke C A, McGee C and Williams C 2009 Using hydraulic modeling to address social impacts of small dam removals in southern New Jersey; J. Environ. Manag. 90 270-278.

Wallace R, Pathak K, Fife M, Jones N L, Holland J P, Stuart D, Harris J, Butler C and Richards D R 2006 Information infrastructure for integrated ecohydraulic and water resources modeling and assessment; J. Hydroinform. 2(4) $317-333$.

Zaharia L 2002 Régionalisation des débits de pointe des bassins versants de la courbure de l'Arc Carpatique (Roumanie), Travail pratique de diplôme, E.P.F.L. Lausanne, 61p.

Zaharia L, Minea G, Ioana-Toroimac G, Barbu R and Sârbu I 2012 Estimation of the areas with accelerated surface runoff in the upper Prahova watershed (Romanian Carpathians), Balwois, Republic of Macedonia, http:// ocs.balwois.com/index.php?conference $=$ BALWOIS\&sched Conf $=$ BW2012\&page $=$ paper\&op $=$ view\&path $\% 5 B \% 5 \mathrm{D}=$ $595 \&$ path $\% 5 \mathrm{~B} \% 5 \mathrm{D}=259$.

Zăvoianu I 1978 Morfometria bazinelor hidrografice, Ed. Acad. Republicii Socialiste România, 174p. 